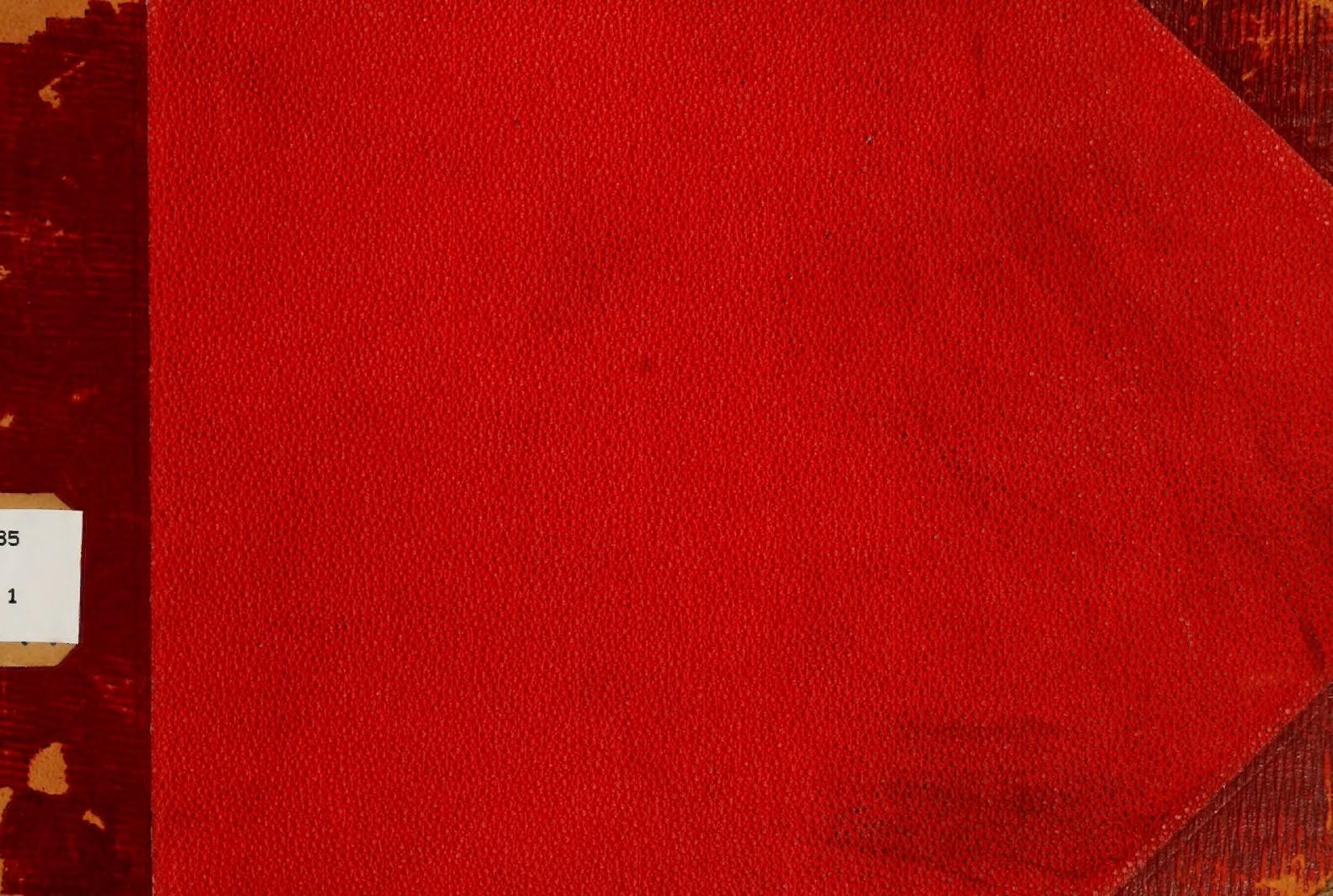




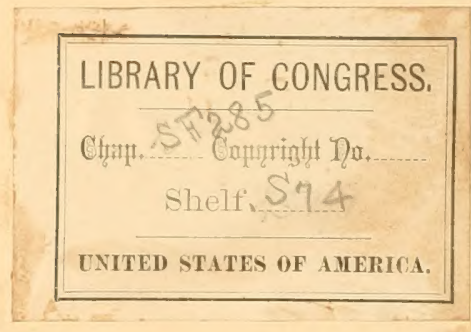





\section{Horse Breeding}

\section{on the}

Western Ranges. 




\section{CONTENTS.}

\begin{tabular}{|c|c|c|c|c|c|c|c|c|c|c|}
\hline & & & & & Page & & & & & Page \\
\hline A LITTLE HISTORY & - & - & & - & 3 & HAVE SHIPPING STOCK FAT & - & - & - & 35 \\
\hline THE PRESENT SITUATION & - & - & - & - & 6 & WHAT NOT TO SHIP - & - & - & & 36 \\
\hline WHAT CAN BE DONE & - & - & & - & 9 & POINTS ON SHIPPING & - & & . & 38 \\
\hline THE FUTURE OUTLOOK & - & - & & - & II & PROSPECTS FOR THE COMING S & SEASON & & & 42 \\
\hline $\begin{array}{c}\text { CAN HORSE RAISING ON THE } \\
\text { PROFITABLE? }\end{array}$ & RANGE & BE MAD & DE & - & 12 & "'WHAT WILL THEY BRING?" & & & & 3 \\
\hline HINTS ON RANCH MANAGEME: & & - & - & & 16 & OCRSELTES & & & & \\
\hline MULE RAISING & - & - & - & & 23 & THE DISSATISFIED & & & & \\
\hline BREAKING WESTERN HORSES & S FOR MA & IARKET & & - & 27 & ARE THESE POINTS OF VALUE & ¿TO YOU? & & & \\
\hline MARKETS AND MARKETING & - & & - & & 30 & TERMS & - & & & \\
\hline SHIPPING SEASON & - & - & & - & 33 & SPECIAL INSTRUCTIONS & 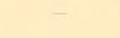 & & & \\
\hline
\end{tabular}

Copyrighted 1892 by T. H. SPAITDING de CO. 


\title{
Horse Breeding on the Range.
}

Can the Horse Ranch be made Profital)le?

\author{
T. H. SPAULDING \& CO, \\ UNION STOCK YARDS, \\ CHICAGO. \\ I 892 .
}




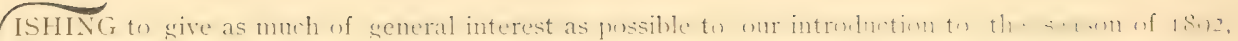

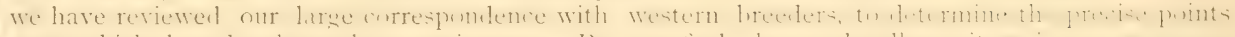

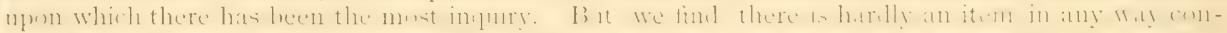

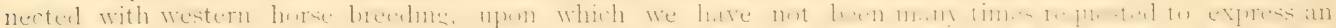

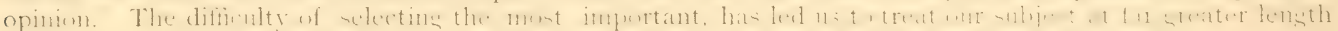

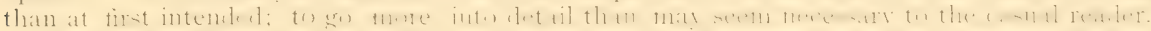

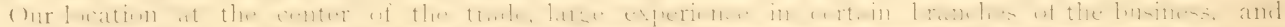

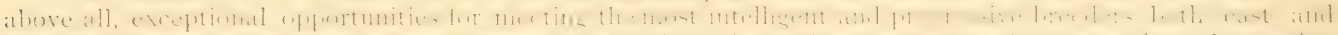

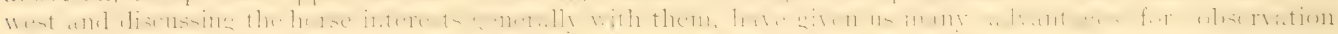

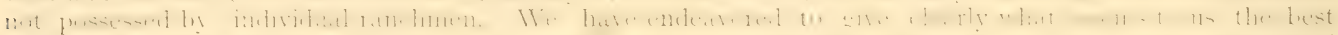

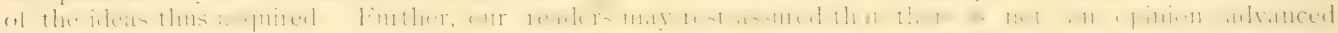

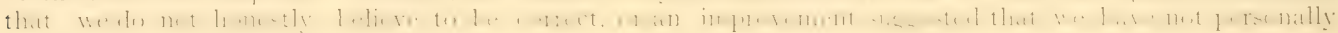
seen tried and proven of practical value.

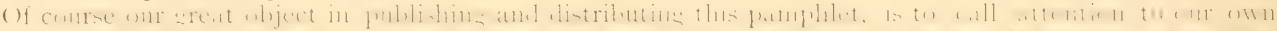

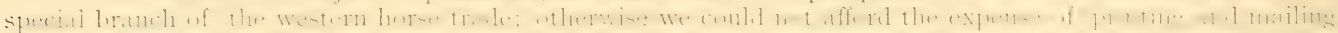

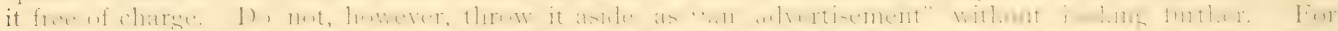

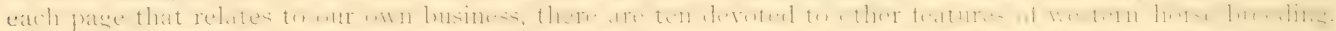

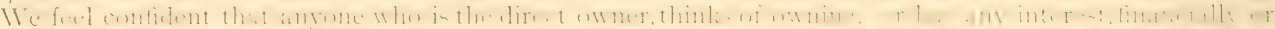

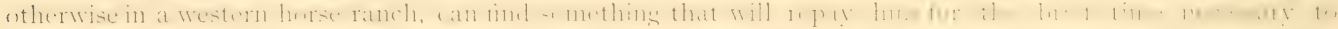

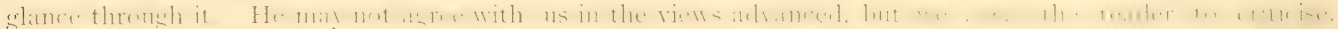

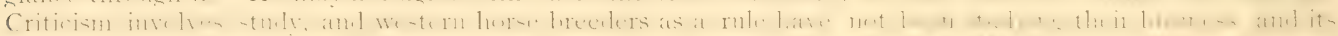

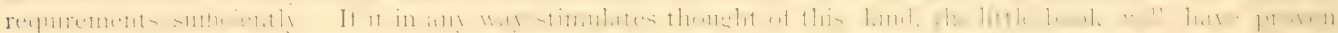
of value to its recipient.

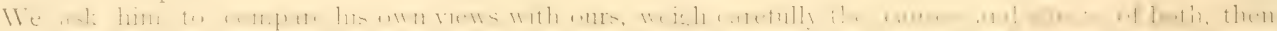

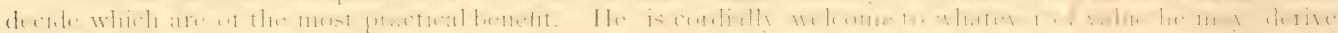
from the suggestions offered. 


\section{A Little History.}

When striving to determine the true present condition of any occupation, we can often derive much that is of real assistance in arriving at a correct conclusion by reviewing its previous history. So, in this instance a brief outline of the growth and development of horse breeding in the west, may prove of interest.

It is not many years ago that horse raising on the range, was almost insignificant as a distinct business, compared with the cattle and sheep interests. $A$ few small herds of inferior stock supplied the cattle men with cow-ponies and such work horses as were necessary. Almost anything was considered good enough for a cow-pony, so, little or no attention was paid to improving the grade of horses, by the infusion of new and better blood.

The great boom in cattle several years since and the grand rush of everyone into that business, had a

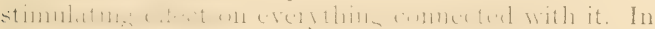
nothing was this result more marked than in horse raising. The immense additional herds of cattle ne- cessitated hundreds of saddle horses to handle them, and in a short time, with the demand far exceeding the available supply, cow-ponies were bringing prices greatly out of proportion to their real value.

Under these circumstances, it seemed only the best business judgment to invest in a band of horses. Buyers willingly paid large figures on the ranch for all the matured geldings, and moreover such a thing as winter loss of any consequence, among this class of stock, was unknown.

It this time also, horse brecders began to realize that it cost no more to raise a better horse than a poor nne and the movement toward improving the herds by the importation of better stallions became general. While of course there were exceptions, men who had for years been breeding the best horses they could, yet they were few and scattered, and up to this time the rule had been to let the stock run wild, a colt being a colt no matter of what quality.

The small southern mares were found to grade up rapidly and the herds were still further improved by bringing in many bands from Orexon, which had been far in advance of the more eastern ranges in the quality of her horses.

Rapidly succeeding the sudden rise and inflated values of cattle, came the reaction and almost total depression of this branch of stock growing. Many who had invested in cattle at high figures, saw their property rapidly slipping away from them, caused both by 
depreciation in value and heavy winter losses. They could see no hope for improvement in the near future and the natural impulse was to save what they had left if possible. Cattle were low and going lower, and the next winter might kill the remainder of the herd, while on the other hand horses were high, the horsemen prosperous and most reassuring of all, horses were considered absolutely safe so far as winters were concerned.

That sentiment, "It's as easy to raise a hundred dollar horse as a twenty-five dollar steer," turned many a cattle man into a horse breeder. But nêrly everyone lost sight of the all-important fact, that it is one thing to raise a hundred dollar horse and altogether another matter to get a hundred dollars in cash for him. As one of the small army converted by this theory, the writer speaks from unpleasant experience.

Horse ranches sprang up everywhere. The finest stallions that money could buy, were imported direct to the ranges and the great west was soon going to supply the whole world with horses. When the home demand for cow-ponies fell off, the enterprising breeder who shipped his marketable stock to the east, found ready sales at prices, which, even while they did not net him quite what he had been realizing at home, still returned a fair profit on his investment.

Indeed, at this period few western breeders who had any number of good horses to dispose of, were obliged to ship their stock. Traders gladly paid good prices on the ranch, shipping the horses east on speculation.

The rapid decrease in extent of the great cattle ranches, opened up the country to the settler, who soon discovered that the sage brush flats of the supposed desert were, when irrigated, even more fruitful than the rich prairie lands he had left. But he required horses to develop his farm, which the neighboring horse breeder could and did supply at good prices.

The western prairie states, Kansas, Nebraska, and the Dakotas, where the rush of new development demanded more horses than were raised within their borders, also made a market which could be easily reached at small expense by trail and where prices were fairly remunerative.

So, with his herd increasing rapidly, both in number and quality, with all these markets taking his matured geldings and barren mares, at figures which left him a good profit on his investment, both of money and labor, the horse breeder felt that his lot was indeed pleasant.

But conditions began to change and each year has made this more distinctly felt.

The settler, who had bought his farming stock from the neighboring breeders, soon realized that he possessed the same advantages for stock raising, as did this neighbor and it was not long until he became 
in a small way, a horse grower himself. This soon had a serious effect upon the home market.

Then the subsidence of the emigration boom, combined with largely increased interest in horse breeding, in the western prairie states, Kansas, Nebbraska, etc., practically closed that outlet for the surplus of range-bred horses. At least, the lessened demand forced prices down to a figure that the breeder could not take except at a loss.

This left the markets of the extreme east the only recourse for western breeders; the only section that could take the immense number of horses that were, and are now, maturing every year on the ranges.

As we have said, the first shipments of range-bred horses to the extreme east, found ready sale at good prices, but this desirable state of affairs has been steadily growing less satisfactory. Prices have gone lower and lower, sales have been more and more difficult to make, until the present discouraging situation has been reached.

That this has been caused by the general market for business horses all over the country growing weaker, is unquestionable. But what has caused this depreciation throughout the whole United States, is the real point which we wish to bring out by this rcview of events, that are doubtless as familiar to our readers as to ourselves.

This fact, which we are so particularly anxious to impress on western breeders is, that the same causes which brought about the boom in horse breeding on the ranges, had a precisely similar effect throughout the whole country.

This was especially true of the corn growing states, where the live stock interests in all branches, are admittedly greater in the aggregate, than in any other section of the country.

The farmers of this region, whose main dependence had been cattle, reasoned the same as did the ranchmen, when they saw their stock depreciating so rapidly, that there was little profit left in growing it. Horses were high, and could be raised at nearly as low cost as steers, so nothing could be more natural than to cut down their cattle and breed more horses. These horses were necessarily sold to realize profit from the business and this immensely increased production has had its effect on the general markets.

These markets might possibly have withstood the strain of the unusually large offerings of common business stock which the entire country has turned off during the past three or four years, had it not been for the extensive and unlooked for development of horse saving inventions. Probably the most felt of any of these, has been the application of electricity and cable power to street railways.

The street car systems formerly consumed immense numbers of a certain class of horses, to which the better grade of range raised stock was well suited, and it seemed for a time a great opening for the western 
breeders. Electricity has not only practically closed this market, but what is still more disastrous, has thrown into competition with the western stock on the open markets, the large number of native or eastern raised horses which had been formerly required for street car consumption. Moreover, not only in the case of street cars alone, but the belt lines, private switches, etc., in the great manufacturing centers, have done away with an immense amount of hauling and trucking, which fact has had its share in depressing the values of business stock.

In substance, the western breeder has in a constantly increasing degree, been obliged to place his horses on the eastern markets, and the competition with eastern bred stock, which has been steadily growing greater, has been crowding prices down at a very rapid rate. Whether ke can continue this competition successfully, and if not, what he can do with his stock on hand, we will consider at length further on.

\section{The Present Situation.}

Few who have not investigated the subject carefully, can fully appreciate the extent of the horse breeding interests on the western ranges. In place of the scattering herds of Spanish and Indian ponies, comparatively few in number and poor in quality, the broad free pastures of the west are to-day grazing over one million horses of every conceivable size, age and breed. This immense number is divided amongst thousands of owners, from the poor farmer with his few colts, bred originally from his team of work mares, to the great stock company with thousands of brood mares and scores of the finest imported stallions. Even the merchant and mechanic are represented, many of the town dwellers having a few head of breeding stock ranging in the vicinity of their homes, looked after by a neighboring ranchman, or rounded up occasionally by the owner, at his leisure.

But the great majority of the horses on the range to-day, are in bands of from one hundred to five hundred, owned by men whose sole occupation is their care and management. 
There is not more variety in the ownership of the component parts of this vast herd, than there is in the quality and breeding of the stock itself. Everything is represented, from the descendants of the native mustang, to the trotter and thoroughbred of royal lincage, the produce of steck broush te the nountains from Kentucky and other sections of the east. Nor is this great variety in size and breeding noticeable only in distinct herds. On almost every horse ranch that numbers its stock by the hundreds, can be found individuals ranging in quality from the Indian "cayuse" to the imported draft horse. This is one natural result of the suddenly awakened interest in horse breeding, where opinions as to what type or purpose to breed for were so diverse, or rather, where so many who embarked in the business had no well defined idea of breeding for any distinct type at all.

It is a great heterogeneous mass, containing much that is good, more that is fairly so and a very great deal that is absolutely worthless, or worse, an actual encumbrance to the owner.

As we have before said, the majority of breeders went into the business several years since, attracted by the great profits and comparative safety of the investment. Almost without exception, their original stock was purchased at high figures, and in a great many instances, their herd as it stands to-day represents their entire capital and the labor of several years; for, as a rule, the income from sales over and above what has been necessary for current expenses has been invested in stallions and other stock, in other words has been reinvested in the business.

Necessarily living more or less remote from markets, and thus not realizing that the value of common business horses has been steadily falling for the last three or four years, the past season with its uniformly reduced returns from shipments, has brought home with crushing force to many breeders the fact that their ranch is no larger paying dividends, and still worse, that their original investment has depreciated in value alarmingly.

To those who have kept thoroughly informed on the markets and other matters pertaining to range horse breeding, it seems singular that this condition of affairs should not be more widely known among those most interested, but no industry of such great extent was crer less organized than this. The cattle and sheep men have had their trade journals, but aside from an occasional article in one of these, the horseman has been able to learn only from experience, which to most has been a slow teacher.

After the demand for cow-ponies had virtually become a thing of the past, there was still a limited home trade in horses of a better class, but the almost universal interest in horse raising which induced the farmer, the merchant and the mechanic to have each his own little band has practically closed the home market to the ranchman. True, it is still possible to 
seII an occasional horse at home for a fair price, but the breeder who can dispose of any considerable number in this manner is an exception.

So the extreme east, that section which consumes more horses than are produced, is unquestionably the only market to which the western breeder can look, to take his surplus stock and in this field the ranchman has been confronted with a market over-supplied with such horses as he had to offer, with prices proportionately low.

To sum up: the condition of the range horse interest is, in our opinion, about as follows:-

Of all the hundreds of thousands of horses on the western ranges, which represent millions of invested capital, a large proportion are worthless as a basis on which to build up an improved grade of stock. Through shrinkage in values from various causes, horses of all classes have depreciated and the poorer grades are worth less than half what they were a few years ago, yet sales are difficult to make even at the prevailing low figures. At these low prices they can be raised only at a loss; in fact the majority of breeders cannot but be losing money at present. While there are many thousand really good horses on the ranges, they are not in sufficiently good shape for market, to enable them to compete on an equal footing with the increased output of eastern bred stock.

With this condition of affairs generally understood, there is little wonder that the western horse breeders are, as a rule, depressed and despondent; that so many are anxious to get out of the business. It is merely repeating the history of similar periods in both cattle and sheep breeding. The same old story of everyone rushing in when the industry is at the height of its prosperity, which tends to still further intlate values and when the reaction comes, being just as anxious to rush out of it, which bears prices down yet lower. Every intelligent breeder is fully aware that the present state of affairs is serious and that practically drifting along, as most have been doing will not turn the tide, toward prosperity. There must be some remedy, which even if it will not correct matters altogether, may prove of benefit to those who adopt it.

As we stated in the introduction to this little pamphlet, we do not advance our opinions as final and absolutely correct. What views we may submit, are based on extended experience and careful study of the matter, and we are honest in our belief as to their soundness, but no man is infallible and we may be entirely wrong. TVe have given our reasons in full and each of our readers has equal liberty of forming his own conclusions from them. One thing however is absolutely certain; effective thought and prompt action are needed to bring horse breeding in the extreme west back to its former prosperous condition. 
er horses and breed them better. Whether this is the necessary move toward relief and, if so, whether it can be done successfully, are matters that those most interested must decide.

We can best express our own opinion, by reproduc-

\section{What Can Be Done.}

Our measure of success in any direction is, to a great extent, determined by our ability to anticipate the future and shape our actions to meet its requirements. This we can only do by studying carefully both the present and past and endeavoring to form our judgment from what they teach. So-called luck may sometimes play its part, but it is a poor dependence.

Applying this rule to the matter in hand, it must be evident to everyone that the present depression in horse breeding interests on the ranges has been largely caused from an over-production of poor stock. While depreciation in prices has contributed in a great measure to the result, horse breeders in every section of the country have also had this to contend with. The range horseman has suffered far more because the almost uniformly poor grade of his stock has made the inevitable competition with the eastern farmer so unequal.

If this judgment be correct, the natural remedy that suggests itself is for the western breeder to raise fewing here a letter written some weeks since, to a personal friend who had asked us what we would advise him to do with his horses. His band numbers about 250 head of all ages and sizes and is in quality about an average of range bred stock. Our reply was as follows:-

\section{DFAR}

It is diflicult for us to reply definitely to your inquiries of recent date. We agree with you that the present situation is discouraging, but we have no better means of knowing what the future will bring forth than have you. You ask us what we would do were we in your situation, and this much we ean tell you frankly; but think the whole matter orer carefully aud decide it for yourself. Do not take our advice as final.

In the first place, fully one-half or more of your horses are practically worthless, at least to you, for they are not fit to breed from. Fortunately, howerer, the eastern markets are not yet so bad but what they can be sold and you can realize something from them. Judging from your last seasons' shipment, these "culls" can be made to net you from $\$ 15$ to $\$ 25$ per" head. So first:-and we cannot emphasize the importance of this point tor much, cut your band down to the very "tops" at the earliest possible moment.

Every dollar you realize for Jour poor stock will be that much clear gain, for the day is coming and coming soon when these 
serub horses will not hring one dollar on the markets. Frankly, you know as well as ourselves that they are worthless except for cow-ponies, and the eastern people who are buyiug them at present are soon going to discorer this fact also. When they do, you cannot give them away.

Cut out ererything that is not increasing in value, either in growth or breeding aud do not leave a matured wild gelding or barren mare on the place. Snch stock is not paying a profit, while you can use the money to fur better adrantage. Dispose of every superthous or inferior animal you own, at the earliest moment that they can be made tit for market.

We know that with your stock grazing ou a free range and the cost of running five humdred but little more than that necessary to handle one-fourth that number, it is dillicult to see the wisdom of this cutting down, but we can say to you houestly and frankly that if you do not realize on your poorer stock at once, you nerer will.

After pruning your baud down to the quick, if rou still wish to continue horse breeding as a husiness, we would adrise jou to seleet and reserve say fifty or sixty of your best mares. If you have not th.t many which are realls good, ent eren closer and buy enough to make up the number. Undex no cireumstances breed a mare that is not sound, young and fairly well-bred, besides haring size aud quality. Do not be afrail of getting them too good; you cannot do it.

Now comes a vital point and oue that will, in a great mensure, decide your future suceess or failure. Consider loug and carefully what type or kind of horse, will, in your judgureut, sell hest in the future. Right here a word of caution, Fight sliy of trying to breed speed, either trotters or gallopers. If you should not get it, (aud you have a huudred chances to one against you, with only common mares to breed from) your colts will be as a rule toosmall to liring much on the open market. Blood is of the greatest value, but a fast bred horse that cannol go fast enough is the poorest property on eartl.

It seems to 11 , that the most cortain results in tollars can be had from breediug for a type of horse that will, if handsome ame stylish enongh, chass as a coacher, while if he falls short of this in quality and looks, will still be large enough for any elass of work. This matter is of the crreatest importance, so weigh erery posibility earefully before deciling detinitely.

When jon have settled this and mate up yom mind which of the best known and must firmly established hreeds of horses will, in your opinion, prouluee what fou want, buy the very best stallion of that breed you can fiud. Do not hesitate at a few dollars in price, for the old rule that the best is always cheapest, is nev. er so true as in an instance of this kincl. The quality of this stalliou will have ererything to do with your ultimate suceess or failure.

Another point-after selecting your type, stick to it. Do not breed draft horses one year, trotterw the next and so on. There is a great distinction between grating, eross breeding and the mixture of half a tozen lifierent breerls. A horse that comes from the indiscriminate mixture of sereral dirterent distinct breeds, no matter how pure each may he, is just as much a mongrel as the serubhiest "Hroncho" that ever disappeared in a cloul of dust when you wanted him.

1)o not try to originate new breels hy theoretical crossiug; you cammot afiord to try experiments of this sort. Select some old stambaril beest that has stool the test of time and then use every trort to grate your entire herd up to as near this standaril as possible. I ou will find that there is far more proflt as well as pleasure in a small herd of gond horses, than in a big band of scrubs that are actually not worth the free grass they eat. 
We have some ideas in regard to ranch management etc., which we will gladly discuss with you when you come east next summer.

We hare answerel your inquities as fully as possible and lope that you may tind these suggestions of ralue, at least as food for thought.

Tery truly yours,

'I. H. Spaulding \& Co.

The above letter gives our views as fully as would a more elaborately written article. The opinions advanced are subject to such criticism as the reader chooses to make. WV only ask careful consideration before condemning them altogether.

\section{The Future Outlook.}

What will actually occur of course no one can tell, but in this collection of our opinions on the western horse business, it may not be out of place for us to give our ideas of its probable future.

At no time since the civil war have common business horses been so low all over the country as at present. But to offset this, it is an admitted fact that during the greater portion of this period, horses have been far higher in proportion than any other class of farm stock. So, while they are low at present, it is possible that they are only resuming their natural relative value.

The demands caused by the growing development of the country at large would easily meet the greatly increased production of this class of stock, had the many inventions for saving horse power not multiplied so rapidly and it is this very matter, that is the great element of uncertainty in the future of horse breeding.

How soon steam and electricity will do away with horses altogether, except for purposes of pleasure 
only, is a question of vital interest to the horse breeder. If the present rate of progress continues, it would certainly look as though practically this condition of affairs would be reached at no very distant date. While it is not likely to come during the life-time of those at present engaged in horse raising, yet the constantly increasing effect of this movement is a matter for grave consideration.

There certainly is not at present and probably never has been, an over supply of really good horses. High class stock of all kinds, whether coachers, drivers or saddlers, is always scarce and high. More. over, the rapidly increasing wealth of the country is every day adding to the demand for these horses and we believe it will be a long time before they are a drug on the market.

There is not the slightest doubt that none but the very best grade of horses can long be grown at a profit. The days of the scrub are numbered. The country already has more of this kind than can be used.

Do not hold common horses for an advance in prices. It will never come.

\section{Can Horse Raising on the Range be made Profitable?}

Taking into consideration the circumstances which at present govern horse raising throughout the country, the matter of possible profit in range breeding is narrowed down to the one question.

Can the ranchman compete with the eastern farmer?

Theoretically, it would seem as though he could easily do so, providing he raises equally good stock. Perhaps the best method of arriving at an intelligent conclusion, will be to compare the advantages of both.

The strongest point in favor of the western breeder. is that his pasturage costs him practically nothing. While the farmer in the east must raise his colts on land that represents so many dollars invested, with corresponding demands for interest and taxes, the range breeder as a rule has to own only so much land as will produce his necessary hay, and even this the government has virtually given him.

Again, the ranchman can graze his stock for 
nearly, if not quite the entire year, while the farmer must stable and feed his animals for at least five months, involving more expense for buildings, besides fodder and grain.

Further, the ranchman can breed to better advantage than the farmer. With scores of brood mares, he can afford to own the finest stallions and breed his mares at far less proportionate cost than would be the case if he had to pay for the services of a horse. This gives him the profit of the stallioner as well as of the breeder. Owning his stallions, he can breed far closer to a certain standard type than can the farmer, who is often unable to secure the service of such a horse as he may desire.

Another, apparent, advantage of the ranchman lies in the fact that he can handle a large number of horses at a proportionately small expense for labor.

Another point of great importance to the ranch owner is, that range bred horses are, as a rule less subject to disease and to accidents, which so often ruin the selling value of a farmer's colt.

With one last item we will have about covered the western breeders' side of the argument. This last point is the most important that can be advanced in favor of the range bred horse. Summed up briefly: a colt raised on the range has, size and breeding being equal, much better wind, better legs and feet and incomparably more endurance than a farm bred colt. Why this is so, is so well-known to our readers that it is unnecessary to dwell further upon it. Suffice it to say. that we are using every effort and spending thousands of dollars in advertising every year, trying to do our share in convincing the eastern consumer of horses of the truth of this fact. The only way to permanently secure the practical benefits of these good qualities to the side of the ranchman, is to breed the range horse to equal the eastern colt in every other respect and his additional merits will, in time, settle the matter in his favor.

The first and one of the greatest points of advantage which the farmer could claim, is that he does not raise horses as his sole means of livelihood. They are an incident of his general farming. He does not depend upon them to support his family. His brood mares more than earn their keep in working his farm, so the colts when foaled, have practically cost him only the stallion fees.

If the farmer is a business man as well, he will admit, that charging the colts with their proportion of interest and taxes, added to the feed necessary to winter them, they will have cost him considerable by the time they are three years old; but aside from a comparatively small amount of grain, winter feeding has been principally coasse fodder, which could not have been disposed of in any other manner.

The farmers' next point and a very strong one is, that when his colts reach maturity, they are nearly, or quite, broken to work. Accustomed to being han- 
dled from weanlings, he can work with them at odd times during their growth, until when old enough for service, he has very little trouble in training them thoroughly. More important still, it has not cost him anything, at least in money, for with no more help than he would necessarily employ on his farm, he can handle his colts when unable to do other work. On the other hand, when the ranchman breaks his colts for market, he has so many that he is obliged to employ extra labor, usually men skilled in their business, who demand and receive high wages. When breaking his colts, the farmer can soon use them at light work which brings him some return, while the ranchman, having no work of this kind to do, devotes his time and money to breaking the stock alone, getting no profit save in the fact of training the horses. Moreover it takes real work to properly break a high spirited colt and more time than most breeders give to it.

Next, if the argument were a personal one, the farmer would triumphantly exclaim "the brand" and consider that as clinching the decision in his favor. It is useless to deny that the brand is one of the greatest disadvantages which the range breeder has to contend with, in eastern markets. While it is something that cannot be avoided - a necessary evil-yet the the intense prejudice that exists all over the east against it, makes it one of the strongest factors in the permanent success or failure of horse breeding on the range. This prejudice is not caused so much by the brand itself, although it is too often a great disfigurement, but it arises from the reputation that western branded horses have made in every section of the east where they have been sold. The first branded horses ever shipped to eastern markets were the scrubby Texas and Mexican ponies. Vicious, unreliable and practically useless, they were never sold to the same man twice. The popular name for them was "mustangs" and it is difficult to convince a large proportion of eastern men to-day, that a standard and registered trotter is not a "mustang", if he happens to be branded. Many of the poorer grades of northwestern horses have not helped to counteract this prejudice, although lately the really well bred stock, has done a great deal toward improving the reputation of western branded horses in the east. This unfavorable sentiment must be brid down. The good qualities of the improved stock must crowd out the memory of the "mustang."

There is still another factor in the competition, that cuts a greater figure in the net returns from the sales of range stock than almost any other. Should the range breeder equal the efforts of the farmer in every particular, breeding just as good horses, having them just as thoroughly broken and selling them for the same prices, he must still raise them at a less cost of from $\$ 5$ to $\$ 10$ per head, to realize an equal net profit on the ranch. This is the share exacted by the railroads for car- 
rying the stock to market, which is just so much greater in the case of the ranchman than the western farmer, because of the longer haul. While these freight charges may and probably will in time be reduced, yet the proportion will be always about the same.

These are practically the most important points on both sides of this competition between the stock growers of the east and west, as they appear to us.

We have not the space to build up a conclusion by an elaborate process of logic, considering each point, both pro and con, separately. With these factors before him the reader can do that for himself. In truth, the whole question is one that each individnal who is interested must decide.

Our own personal opinion is, that if a man can be satisfied with fair returns for his capital and labor invested, is willing to conduct a business of moderate extent, and desires to engage in a branch of stock raising where the dangers of loss from winters or disease are reduced to aminimum, he will not be disappointed should he continue in horse breeding. One thing is certain, a very large percentage of profit will not be possible, and in fact the business must be conducted carefully and intelligently to insure any margin of profit whatever.

He must raise the very best grade of horses and handle them properly. To do this the number must be limited. Why large bands of horses cannot be handled successfully on the ranges, is something that it is very difficult to explain. It is one of the things which, theoretically, are very simple, but in which the results have almost always been more or less disappointing. So far as we know, breeding horses by the wholesale has been a practical failure in the past and we believe it will always continue to be so. One reason for this undoubtedly is, that really first class stock can be bred only with carefulattention to mating etc., which is impossible when the herd is too large. In addition, the uniformly poor results and great expense of trying to break horses on a large scale, has had much to do with the failure of the most pretentious of the horse ranch schemes.

But there seems to be no reason why a ranchman, keeping no more horses than he can easily care for himself, with little outlay for labor, handling his herd properly and raising the very best and most salable stock, cannot derive a satisfactory income from his investment.

But he cannot do this under the present system of handling horses on the range. A horse that will compare equally in every respect with the eastern bred animal, cannot be, or at least very rarely is, grown under the old plan, of allowing the stock to run wild throughout the year. To be really marketable, a horse must be thoroughly trained, and this is practically impossible, if he is allowed to exist as a wild animal until maturity. But our subject now comes to the 
ways and means of growing the right kind of a horse and we can cover this more thoroughly in a separate article.

To repeat:-Horse growing on the range can be made profitable if the breeder raises less stock, breeds the best and handles them right. This involves a quick and radical change from the present system. Do you care to make this change? If not, you had better get out of the business and that very soon, for you will only grow poorer every day that you continue to breed useless wild scrubs.

\section{Hints on Ranch Management.}

This is something which we are aware many of our readers will question our ability to discuss intelligently. Many who will readily grant that our opinions and judgment on all things pertaining to the markcting of western horses in the east are correct, may consider that they are better posted on practical ranching than are we.

To these critics we will only say that while we have had considerable personal 'xperience in range breedins. we have also had exceptional opportunities for meeting a large number of the most intelligent breeders from every section of the west and discussing every phase of the business and its prospects with them. Nearly all that we have written in this little pamphlet, particularly this portion relating to ranch management, has been suggested by these discussions on this subject, with men who have made horse breeding on the range their sole occupation. They are advanced as suggestions only. Should anyone find in them anything that may prove of value, he is welcome.

Before going further, it may be well to remark that 
no amount of theory, even if carried out to the letter, will make a success of horse breeding, or any other business, without shrewd, economical business management to back it. But this is something entirely beyond the province of advice. It is that naturegiven quality which proves the good business man.

\section{The Management of Stallions.}

In $n o$ one thing in the bistory of horse breeding in the west, has there been shown more reckless waste, more shiftless management, than in the custom of allowing stallions to run at large with the mares throughout the entire season. Possibly the poor quality of the stallions in general use, has not warranted the expense involved by any other plan, but that any sane business man should subject highly bred, valuable horses to this treatment, passes comprehension.

Turning the stallion loose may save some expense for feed and certainly a great deal of labor, but what is actually lost to offset this ?

A stallion running at large will not get one-half the colts he would, were he kept up and not allowed to waste his powers in serving mares unnecessarily. IVhat colts he does sire will not be nearly so strong and vigorous, because of the lack of vitality in the horse. A pure bred stallion, imported as most of them nust be from the east, has, all his life, been accustomed to grain feeding and careful attention. Turn him loose on the range, with only grass as food, at the very season when there is the greatest strain upon his vitality, with uncurbed liberty to his appetite, how can he be expected to get any number of colts, or to give such colts as he does sire, the sturdiness and spirit which they should by right inherit?

If the range breeder intends to successfully raise horses to compete with the eastern farmer, he must adopt a great many of the eastern farmers methods, in place of the easy plan he has been pursuing. Leaving both the great possibility of accident and injury to a valuable horse, and also the fact that his neighbor has almost an equal chance in the benefit with the owner, entirely out of the question, the greatest number and the best colts, can only be secured by keeping up the stallion throughout the year and caring for him properly.

Some of our readers may think it unnecessary to dwell so long on this point, but there are still many: breeders so short-sighted, that they are treating their stallions the same as, or even worse than they would range bulls.

Keep the stallion in a roomy box stable and as he needs exercise, give him free access to a strong corral where he can come and go at will. If his disposition will admit it, (and don't breed from a horse that it will not) work him on the ranch, except during the actual breeding season. During the breeding season, feed liberally to keep him in the very highest 
condition, (which, by the way, does not mean fat) for on this depends his prepotency, that power of transmitting his good qualities to his colts.

How frequently a stallion can be bred, depends to a great extent on the individual. The rule among most successful breeders, is not to allow the stallion to serve more than two mares each day and some prefer that he be limited to one.

The number of mares that can be bred to a single stallion, is a point upon which authorities differ greatly. However, the consensus of opinion seems to be, that the best results can be secured by allowing from 50 to 65 to a matured stallion, if in good condition and in perfect health.

Care should be taken in another important particular. Nothing is easier than to ruin the temper of a highly bred horse by teasing and careless handling, making him vicious, obstinate and often actually dangerons. Aside from the trouble involved to the breeder in using him, this will have a pronounced financial effect upon his value in two ways. He will almost surely transmit his temper in a greater or less degree together with other qualities, to his colts; and should the ranchman at any future time wish to sell him, his market value will be greatly depreciated. So, handle the stallion firmly, never allowing him to forget that he has a master, although under no circums.mu abuse him, for unnecessary cruelty, will just as certainly cause a high spirited stallion to become ugly; as will teasing.

It is too often the case that a first-classstallion, while given a comfortable stable and ample exercise, is utterly neglected as to grooming. Simply because there is not someone to admire his sleek coat and fine condition, it does not pay to neglect that regular care and attention, which is so necessary to keep a stallion in really good form. One cannot afford to treat a valuable stallion the same as a scrub "broncho."

Never feed a stallion drugs or nostrums with the foolish idea that it will increase his powers as a foal getter. Good clean grain and hay, with plenty of pure water, is all that a healthy horse requires. While oats are the standard and undoubtedly the best steady food, an occasional change to other grain, will be appreciated. A horse likes variety in his rations as much as does his owner. It should be unnecessary to mention that a supply of salt, placed where the horse can constantly have easy access to it, is a prime requisite to good health.

\section{Breeding.}

Probably the most important problem that confronts the ranchman who is changing from open range breeding to the system we are advocating, is how to breed his wild mares with his stallion stabled.

There are sereral plans of doing this, each having 
marly earnest supporters. They all require however, that the brood mares should be gathered at the beginning of the breeding season, separating from them as far as possible, the growing colts and geldings. This saves the young stock from much worry and liability to accident, in the constant handling, which breeding the mares makes necessary. It also relieves the brood mares and sucking colts from the often unwelcome attentions of the young geldings.

The brood mares when gathered, must necessarily be either herded or pastured in the vicinity of the ranch, if the stallion is kept in the stable for even a portion of the time.

The custom of many breeders, is to turn the stallion loose among the mares during the day, stabling and feeding him every night. But this, in our opinion, is open to two objections:- first, that the stallion will exhaust his vitality, serving the same mares several times unnecessarily, and second, the danger of accidents, which is of prime importance when even a slight kick may ruin a horse that has cost his owner several hundred dollars.

Another plan, which is growing very popular on the ranges, is to keep the stallion in his stable, driving a small band of brood mares into an adjoining corral, and after determining those that are in season, turning him among them; first removing such of the mares as may give no indications of requiring his services. After covering a mare, the stallion can be easily sepa- rated and driven to his own corral. This we consider by far the best plan in general use, as it reduces the wear on the stallion to the minimum.

But the range breeder can take one more step toward eastern customs. WV sincerely believe that the ranchman can secure the very best results, only by breaking his brood mares to halter and accustoming them to being handled. Without question he will be benefited in at least two ways. It will save time and labor in breeding, besides reducing the chances of injury to his stallion, while it will have a pronounced effect upon the nature and disposition of the colts.

The laws of heredity are inflexible, and "bred in the bone," applies just as forcibly to disposition and temper as it does to size and spirit. It stands to reason that a foal from a comparatively gentle, docile mare, will be more easily handled and trained, than one from a wild beast, whose only idea of man has been a creature from whom to fly.

Just as certain as fate, the horse ranchman of the future must breed civilized horses, not wild ones, if he wishes his business to prove profitable. The surest method of getting clever horses is to brccl them clever. You may manufacture them from wild ones, but it is difficult and expensive to say the least. Besides, experience has shown that it is decidedly uncertain. Therefore, we are confident the breeder who takes the trouble to gentle his brood mares, will get ample returns when he comes to handle even the 
first crop of colts from them, to say nothing of the effect upon succeeding generations, should the plan be followed up.

\section{Care of Young Stock.}

The same principal that makes it advisable to handle brood mares, applies equally to young colts. What use is there in breeding from a gentle dam, if the colt be allowed to grow to maturity, wild as the deer? What docility he may have inherited will certainly be lost.

There is a vast difference between halter breaking a weanling, and endeavoring to subdue the same colt when fully matured, and abundantly able to resist the restraint, for which his free life on the range has taught him to have a deep hatred. Every experienced breeder will testify to the lasting memory of a horse. Once halter broken, he never forgets it. He may fight to the limit of his powers against again being made captive, but when once securely: haltered, he will surrender quietly, if he has ever before been thoroughly taught that man is his master.

It would seem unnecessary to urge on breeders the great benefit that they can derive by breaking to halter every colt that they produce, but as a matter of fact, not one ranchman in one hundred is doing it to-day.

Another advantage to be gained from this is that it necessarily involves weaning the colt from his dam. The benefit of weaning can best be made clear, by stating that the highest veterinary authorities have long since decided, that the colt derives no real nourishment whatever, from his mother's milk after he is six months old. At the same time, if the mare be in foal again, she is suffering from a double drain upon her vitality. She is trying to nourish the colt by her side and at the same time she must supply the demands of the one forming within her. What she gives to one, she must take from the other, as she has only so much to give, and in this case it is the unborn colt that suffers, as well as the dam, while the suckling does not gain any material benefit.

The future size and quality of a colt depend on the condition of his dam and his corresponding development before birth.

Moreover, every breeder knows, that almost uniiormly the greatest winter loss is among mares that become so thin from suckling, that they cannot withstand the serere weather and scanty feed. By weaning her colt at six months old, the mare can get in good condition to go through the winter, and bring forth in the spring a stronger, and in every way better colt, than if she has been struggling along trying to support two lives besides her own.

But the reader will say at once, "this involves feeding the colts through the first winter." Certainly it does and the breeder can make no investment that will 
bring greater returns. Next to suckled down mares, the largest percentage of loss among range horses is in the weanlings. Every ranchman knows how seldom the number of yearlings corresponds with the colts branded the previous season. IVeaning the colts saves this loss, and there is nothing gained in breeding good colts, and letting them die the first winter. Further, it gives ample opportunity to thoroughly halter break and accustom the little fellows to being handled, a lesson they will never forget.

Best of all, liberal feeding the first winter will keep the colt growing steadily, at this very critical period of his life. Without question, the deterioration in size of horses on the range, is largely caused by the winter hardships setting back their growth, in other words, stunting them. If kept strong and growing, through the first season, they will be far better able to withstand the rigors of subsequent winters and, in the end, develop into much larger and smoother horses. So the ranchman can easily get three very apparent and profitable benefits, from winter feeding his weanlings.

The western breeder has one great blessing which he does not always fully appreciatc. This is the quality of his hay. Good clean mountain hay alone, will keep his colts fat and growthy, without using any grain. However, several ranchmen of our acquaintance have tried feeding their weanling colts on sheaf nats, with excellent success. Our critical friends will probably raise the objection, that this feeding will make it necessary for them to become "grangers." Nothing is more sure, than that the days of the old easy range system are past, and that the combined farmer and stock raiser is the coming man in the extrene west.

\section{Branding.}

While the brand is a great injury to the sale of western horses no matter how good, in the eastern market, yet the evil can be mitigated to some extent, by making the brand as small and inconspicuous as possible. The large, ugly brands used by so many breeders are entirely unnecessary and invariably take just so many dollars off the price of the horse, when it is sold.

It is not easy to determine on just what part of the animal, it is best to burn the brand. It will, of course, be entirely out of sight when on the neck, under the mane, but at the same time, it is useless to the breeder as a means of identifying his stock.

In our judgment, the requirements of the eastern markets and necessities of the breeder can be easiest met, by burning a very light brand, either on the right ${ }^{7}$ shoulder, or on the left stitle as far down toward the hock joint as possible.

Under no circumstances brand a horse anywhere about the head. We know the idea that it is best to brand on the cheek, where it will be covered by 
the side piece of the bridle, is very general; but it can seldom, if ever, be thus concealed when selling the animal, and any disfigurement of a horse's head or face, seems to be more disliked by eastern buyers, than if it were in any other place.

More than one brand on the same animal is an added detriment. Brand the colt only once, and have that as plain, simple and above all, as small and light as possible.

\section{Castrating.}

Hundreds of good colts are lost in the west every year through ignorant, careless, or brutal methods of performing this necessary operation. Even when done as skilfully as possible, it necessarily entails great suffering on the colt; but why so many breeders not only aggravate the colt's agony, but still more important to them, jeopardize the life of an animal that represents to them just so much money, it is difficult to understand. Financial reasons, to say nothing of humanitarian ones, should cause them to use every effort that would add to the quickness, painlessness and safety of the operation.

There are several methods in vogue among western breeders, from simply slashing out the colt's testicles with a knife and turning him loose, to live, or bleed to death, as Providence wills, to an elaborate process of clamps, etc.

However, it would seem as though the ranchman could profitably adopt the very best of everything connected with his business, particularly when the cost is comparatively light.

The almost universal method among the veterinary surgeons in the east, is to perform this operation with an crascur, an instrument especially designed for the purpose, which severs the cord and at the same time closes the arteries, thus preventing excessive bleeding. An amateur can use it with precisely as good results as a professional veterinary. In fact it is even more simple than the knife. There are several different styles and makes of these instruments, which can be secured from any dealer in horse goods.

Do not mistake what we say on this subject as being an advertisement for some particular surgical instrument. It is simply in the line of our other suggestions. We consider it, from practical experience, an improvement that reduces the chance of loss in altering young stallions, and it certainly does not pay to breed good colts and then kill them.

The proper time for castrating colts, is something best determined by the individual and the circumstances. It would undoubtedly be an excellent plan to allow some colts, particularly those whose conformation is slim and angular, to run entire, until nearly or quite two years old, thus giving them a chance to grow rounder and smoother. But, as the range breeder must necessarily allow his herd to mix indiscriminately, it is not best to take the chances of 
the young stallions getting his mares with foal. Catch colts are not profitable. So he must, as a rule, alter all his colts during the yearling season.

Another point-it is the common practice among western breeders, to cut off the last two or three joints in a colt's tail, when castrating him. Don't do it. One of the strong points in the selling value of a horse is a handsome, full tail. Banged tails may be more or less fashionable, but the buyers want to cut them off to suit themselves.

While these few hints do not, by any means, cover the entire subject of horse breeding, still they are among the main points. As we said in the beginning of the chapter, they are given as suggestions only. If the reader does not agree with us, he has an equal right to opinions of his own.

\section{Mule Raising.}

The spirit of inquiry as to the probable success of mule raising on the range, seems quite general among breeders in every portion of the west.

At first glance, it would seem that there is much surer, as well as larger, profit in breeding mules, than horses.

The market for mules has always been steady, so much so, that they are nearly as staple as cattle. Mules of a certain class, are always worth about a certain price, while on the other hand, nothing varies so much in selling value, as horses. And mules can be sold much more readily than horses. Shipped to St. Louis, Memphis, Atlanta, or any other of the prominent mule markets, they can usually be quickly disposed of, at wholesale, for fair prices. Nor is it necessary to have them broken.

All these advantages, would be more than sufficient to convince the ranchman that be could not possibly do better than to raise mules, were it not for the fact that it is, as yet, doubtful whether they can be bred successfully on the ranges. 
TVe have in mind a few instances, particularly one Montana breeder, who has made an unqualified success of mule raising. In these few cases, there seems to be no difficulty in getting a good percentage of colts and raising stock of fair quality. But none the less distinct, are the many instances that have come to our knowledge, where, starting with everything apparently favorable, the experiment has proved a dismal failure. Further, it is difficult to assign a reason for such disaster. One probable cause, has been the lack of thorough practical knowledge of mule breeding, as differing from horse raising, on the part of the experimenter. There is undoubtedly a certain amount of practical experience necessary, such as properly caring for jacks, etc., but neverhaving engaged in this branch of breeding ourselves, we are not qualified to advise intelligently.

One point we have, however, investigated fully. With the idea of engaging in the business ourselves, we took occasion some months since, to carefully look over the probable market for range bred mules, and to ascertain if possible, what class of stock would bring the most profitable returns. The substance of the information given us by the most prominent mule dealers in the country, when interviewed, is, that the few range mules now marketed, are "too small, not fat enough and have that horrible brand," all of which prevent their bringing the prices they should.

Taking the objections in the order given, the infer- ior size can cone from two possible causes. The parent stock may be inferior, or, since mules are by nature a "warm weather animal," they will not develop properly when obliged to pick their living on the range; winter cold and starvation stunts their growth. This may or may not be the case, but the fact that the Kentucky breeder feeds his young mules liberally from the time they are weaned, in place of allowing them to subsist entirely on even his splendid blue grass pastures, would tend to prove its truth.

The matter of breeding from good stock is something far more easily regulated. There are thousands of mares on the ranges, that would make first-class brood mares for mule raising. In fact, we sold several hundred such, during the past season, to mule breeders in Kentucky, who bought them for this purpose alone. But they will not produce good mules, if coupled with some little, worthless, jack rabbit of a jack. "Like begets like" and such a jack is not much more liable to sire a good "sugar" mule, than he is to get a race horse. The next objection of the trade, is the poor condition of the western stock when marketed. As most who are interested in the subject know, the mule market is at its best, during the late winter and early spring. This comes from the fact that the great consumption of mules is in the cotton and sugar growing sections of the extreme south, and it is at this season that the needed fresh supply of stock is purchased. It is obviously impossible to get 
stock off the rangre at this season, thoroughly fat and sleek. Therefore, some system of feeding for market is necessary, in order to compete with the eastern breeder, who fattens his mules for market much the same as he does cattle.

Again comes that great difficulty of western breeders of every kind of stock--the brand. As in the case of horses, we can only say, make it small and light.

During the course of our investigation of this subject, several extensive mule dealers made us a suggestion that seemed at the time, and we still believe, capable of being made profitable. It was, to breed the very best mules possible and ship them to lientucky, Tennessee or Missouri when a'cunlings, say at six months old. To make this idea perfectly clear to all our readers, it may be necessary to explain briefly the system under which mules are generally raised, in those sections where their production is made a specialty.

As a rule, the mules are bred by farmers owning only a few mares, which they work during the greater portion of the year. When weanlings, the mules are bought up by parties who make a business of growing them in considerable numbers, picking them up here and there around the country. Sometimes the mules again change hands, being bought by the "feeder" when nearly old enough for market, and are systematically fattened and gotten in the very best sale con- dition by him. They are then usually sold at one of the few great mule markets, to a trader who takes them south and retails them to the actual consumer, the planter.

The opinion of those experienced men, who suggested shipping the western bred mules as weanlings, was, that if bred from equally good stock, they should and probably would bring as good prices as the native colts.

As nearly as we can learn, weanling mules have brought in Kentucky and Tennessee during the past two or three years, from $\$ 40$ to $\$ 80$ per head. The latter figure is, of course, an exceptional price for a very choice colt only, but if our information is correct, an average price of $\$ 50$ is not far out of the way. At this figure there would certainly be a good margin of profit in breeding them, providing one could secure a fair percentage of colts. The cost of shipment would be comparatively light, since a large number of the little animals could be loaded in a car.

We are not prepared to advocate and do not wish to be understood as arguing, either for or against the scheme. We have simply reproduced it as it was given us. The data quoted we believe to be correct, but as to whether the prices for mules, big or little, will continue to be as good during the next few years as they are at present, we cannot advance even an opinion.

There certainly seems to be no reason why with 
equally good mares and jacks, as good a mule cannot be bred in Wyoming or Montana, as in Kentucky or Missouri. A really good jack cannot be had for a small price, and we believe there are many points to be studied carefully, when investing in one. Chief among these, are the quality of his colts, (the jack's personal appearance is not always a sure criterion of this) and his readiness in serving mares. The purchaser can, however, easily satisfy himself regarding these most important elements in the jack's value, if he purchases one that is old enough to have done service the previous season.

The mares must also be well haltered and gentle enough to breed by hand; but we consider this an advantage in horse breeding as well.

Possibly by winter feeding, the mules could be raised to maturity on the ranch, and develop size and symmetry equal to the Kentucky animal. As we said in the beginning of this article, we know a few breeders who have been, and are now raising fairly good mules on the range, handling them almost presisely the same as they do their horses.

A final word of caution-don't raise poor mules. The market for little, scrubby mules, is just as bad as it is for poor horses. Even the cotton planters, who formerly used large numbers of these small mules, are insisting on having a better grade of stock. If you raise mules at all, raise good ones. Breed the best. Produce something that is wanted and you will get your price for it. Raise something that no one wants, and you cannot give it away.

We are aware that our article on mule breeding is hardly complete, but we will not advance any theories that have not been proven by practice. If any of our readers should desire more definite information regarding markets, etc., we will gladly do all in our power to aid them in securing it by correspondence. 


\section{Breaking IVestern Horses for Market.}

Almost every day throughout the entire year, we receive this inquiry from western breeders:- "Shall I break my horses before shipping them ?" Invariably our answer is, under no circumstances cudearor to break horses which jou intond to markct this scason.

Such of our readers as have received our circulars etc., in the past, may say that we are going squarely back on what we have heretofore advised on this subject; particularly in the little pamphlet on the range horse market, published in I\$90. On the contrary, we have not receded from the thcory then advocated, but have simply found it impracticable to carry out profitably.

Of the hundreds and thousands of western horses shipped to us as broken, during the past two years, hardly one per cent of them have proved fit to be offered as thoroughly gentle to all harness.

Horses sold on the eastern markets as trained to harness, must prorc that they are such, before the buyer will take them. Everything must be positively guaranteed. If we sell a western horse as well broken, and when tried, he shows the slightest indication of not being perfectly used to his work, the buyer rejects him instantly, and the horse will not then bring any more than he would had he never been handled at all. Too many breeders have the idea that they can sell as broken, horses that have been driven a few times, in fact, just well bitted. Such animals are only ready to begin their real education. Neither will a horse that drives fairly gentle, but that has not been taught to carry his head or handle his feet properly, sell for much of anything in the east; in fact, not as much as he would bring wild.

There are many ranchmen, who do not understand what is really required, to make a horse grade as well broken, on the open market. Besides being clever, and perfectly taught to respond to every motion of the bit, he must carry himself well in every way, head up, good action, if a road horse or coacher, and a strong steady puller, if a work animal; stand quietly when hitched, either on the street or in the stable, and be clever and gentle to handle when harnessing etc. It is unnecessary to mention, that ugly traits of temper will surely injure or ruin his sale.

All this cannot be taught a horse in a day, or a week, or a month. It takes months of steady work and infinite patience, even when a colt has been accustomed to being handled from a weanling. How much more difficult is it then, when the colt has 
grown up wild and absolutely free from restraint. With all this natural fear to overcome, before even the rudiments of the horses education can be taught, and with the ever-present possibility that this old wild spirit will crop out at any time, there cannot be any certainty of breaking the colt, except at a cost of time and labor, that leaves very small chance for profit.

Do not misunderstand us as saying, that horses raised wild on the range until three or four years old, cannot be broken. They can be and thousands are well broken every year. But we do claim, that the ranchman cannot profitably spend the required time and actual cash outlay, necessary to properly break any number of matured geldings. He will not get the expenditure back, in the added prices the stock will bring, over what he could get for them wild. Having seen this fact proved many times during the the past two seasons, is the only reason of our change of opinion as stated. Our advice to the breeder who has stock to market this season, is to send them forward just as soon as they are thoroughly fat, without attempting to handle them in any way. Put in the time breaking your yearlings and two year olds.

It is practically impossible to market horses the same year they are broken. The work and worry prevents their keeping in good flesh. which they must have to sell well, unless fed on grain, which is usually too expensive. Break the range colts as the eastern farmer does. Acrustom them to halter when weanlings, teach them more the next year, still new lessons the next, and finally at three's, finish them up. Then they can be shipped the following season, and with a little hardening, will be in first-class shape to sell.

Another very important point which many do not appreciate, is that only a small proportion of the matured stock on the range to-day, is worth breaking at all. Unless of good size, smooth and fairly good looking, a horse will not repay the expense of training him. A small or rough animal will not bring a cent more broken, than he will bring wild; in fact not so much. When totally unbroken, he looks better to these eastern buyers who invest in this class of stock. They are obliged to view him from a distance and he looks larger. If you do break matured horses, break only the very best, and sell the others as they run.

Further, never ship well broken and wild horses in the same consignment. To derive any benefit from the broken stock, it must be removed from the incubus of bad company, and besides, the market for this kind is entirely separate from that for wild and half broken animals.

$W^{\top}$ e cannot attempt to give even a few of the hundreds of different methods of breaking colts. Almost every experienced breeder has his own plan of doing this, and it is not so much the means, as the result that is of importance. Kindness, which does not by 
any means imply lack of firmness, is the prime requisite for successful horse breaking. Proceed slowly; teach the colt one thing only at a time. One lesson thoroughly learned, is far more satisfactory in the end, than confusing the colt with a jumble of half a dozen, which he does not understand.

Do not raisc horses that it will not pay to break, and begin their education at six months old.

\section{Halter Breaking.}

This is another matter upon which we hold a different opinion than formerly. Actual results convinced us last season, that as a rule, halter breaking does not add sufficiently to the selling value of a horse, to warrant the expenditure and chances of accident, which it involves.

Particularly, do not break horses to halter, that you wish to dispose of this season. The worry is bound to cut down their condition, and flesh is everything in their sale.

While the fact that a horse can be shown to work cleverly to halter, may occasionally enhance his value, yet, if he is sold to do this, and when caught for delivery acts more or less wild, (as most of them do,) the sale is ruined. If buyers get the idea that an animal has been spoiled, it will be difficult to sell him at any price.

Taking everything into consideration, we do not believe the breeder will find that it will pay him, should he break his horses to Iead only, before marketing them. As we said before, the time can be spent to much better advantage working with the younger stock. 


\section{Markets and Marketing.}

This is unquestionably the most pressing and important problem that occupies the minds of western horse breeders at the present time. The matured stock on hand must be converted into money for present needs. While the future must also be considered, the obligations of to-morrow must be met first.

The question as to what field the ranchman can look to take his stock, has been covered in the previous pages, so it is unnecessary to repeat it. IVe do not think, in stating that the extreme east is the western breeders only outlet, we advanced an opinion which is not generally believed. All ranchmen are as fully aware as ourselves, that the home market or the extreme western farming section cannot be depended upon to take any quantity of horses at living prices.

It is a vain hope to hold marketable stock on the ranch, trusting to malie a sale to the eastern speculators, who formerly operated so largely in western horses. Prices declined in the east before they did on the ranges, and the unsatisfactory results of later years, have effectualily eliminated the speculator as a feature in the range horse trade.

To make a cash sale of his horses, the ranchman must ship them himself. The sooner he appreciates this, the more money he will get for them. He must come to it sooner or later. If later, they will not be worth so much as they are now. IVhen starting out to seek a market, the range breeder finds himself confronted with many difficulties.

With cattle, there are certain recognized markets, where any number, of any grade, can be sold at any time for a more or less fixed price. For broken, unbranded, native raised horses, Chicago, St. Louis and Buffalo are the great centers of the trade, and values are practically standard.

But there is no central market for unbroken western stock; no point to which the breeder can ship them, certain of finding a buyer for his whole consignment, at a fair price. Wholesaling western horses has never proved a success. Dealers who will handle them at all are scarce, and the few who will buy them in any quantity, will not pay the breeder anywhere near what the stock is worth. Eastern traders prefer to handle native, broken horses, as they are more staple and easier to sell.

The only way in which western horses can be disposed of, so as to realize anything like fair value for them, is at retail, direct to the consumer. In other 
words, the ranchman must hunt his market, selling his stock where and to whom he can.

If the sweeping statement, that the east viz: those states lying east of the Mississippi, is the best and only market for these horses, applied equally to each and every part of that vast territory, the western breeder would have little trouble in placing his horses. Unfortunately, however, it does not. In calling that the best market, we mean that it is that portion of the country which consumcs the greatest number of horses of all classes, and that different points within that territory, will pay the highest figures for unbroken, branded horses, that can be secured anywhere in the United States. To be successful in disposing of his horses, the ranchman must strike these markets.

Without an actual knowledge of the field, he is obliged to determine his objective point at random. He may place his stock in a town, where a large number of the same class of horses have been sold just previous to his arrival. Should this be the case, he will find it practically impossible to dispose of his shipment, unless at ruinous prices. There are only a certain number of persons in every community, who will buy these horses at any figure. With this demand oncesupplied, the market at that point is closed until another season. Again, the ranchman may have the ill luck to strike a section of country, where the prejudice against western branded horses is so strong, that he can hardly give them away. Unfortunately, these places exist, indeed, are only too common, Further, we advise the intending shipper to beware of a town, where the street car system has recently been changed from horses to cable or electric power. In every instance of this kind, large numbers of street car horses have been closed out regardless of value, and the demand for cheap stock has been more than supplied for months to come. Still worse, these slaughter sales have fixed the standard of prices too low for anyone, but a great corporation, to stand. All these points are of vital importance, in deciding as to the availability of any locality as a market. They mean quick or slow sales, low or good prices.

When a town is located, that has every indication of proving a satisfactory place to dispose of the shipment, it must be worked up in order to sell the stock quickly. The horses cannot be sold unless the buyers can be gotten to look at them. This means advertising, and advertising has become a science. To be effective, it must be thorough, novel and attractive. It is expensive, but nothing can be done without it. A few years ago, the arrival of a shipment of western horses in any eastern town was soon noised abroad and buyers fairly fell over one another, to get their share before the stock was closed out. It is different now. The buyers must be coaxed to come. They must be made to believe the horses are a good investment.

When possible buyers are secured, then comes the 
test of the shipper's ability as a salesman; to get every dollar that can be, had for his stock, and yet to sell them. It costs money, and a great deal of it, to hold horses in the east. The shipper must know what his stock is worth on the market, when to take an offer. and when to refuse one, in order to get all that the horses can be made to bring.

We have given as brietly as possible, the substance of what we know about marketing this stock. Our experience has extended over several years, during which time we have sold more western branded horses than any firm in the country. WVe have sold them from Kansas to New York, from Maine to Georgia, at wholesale, at retail, at auction, in fact tried every experiment that could be thought of, to determine definitely just how, where and when they could be sold, to bring the most net money on the ranch.

The points mentioned are the ones we have found absolutely essential, to secure satisfactory results from shipments of these horses. They cover every necessary particular. We have no secret method of selling the horses consigned to us. We simply select the most promising markets and work them for all they are worth.

If the ranchman can himself control all the requirements necessary to place his stock to the best advantage, viz: if he knows just where to ship them, how to work up his market to secure biryers, lnows the highest dollar those buyers can be made to give when he gets them, we can not be of service to him. But those breeders who are not certain of these things, and cannot afford to try expensive experiments, we ask to read carefully what we have to say, regarding our system of placing this stock. We know the markets, and have the means of selling your horses satisfactorally. We will place our knowledge, experience and facilities at your service if you desire them.

\section{Southern Markets.}

There seems to be a general interest among western breeders, as to the markets in the extreme south, so definite information regarding them may prove acceptable to our readers.

In our opinion, that section of the country cannot be depended on, as a certain and profitable field for range-bred horses, for several reasons.

Mules are the main dependence of the farmers and planters, the only grade of horses for which there is any demand whatever, being smooth, blocky mares.

Another great objection is, that the trade in both horses and mules throughout the entire south, is controlled by regular dealers or traders. Crops are uncertain, and almost invariably the planter is obliged to purchase his necessary work stock on credit This shuts out the ranchman from the retail trade, and the regular dealers, being obliged to make a sufficient margin of profit on their sales to pay them to wait a year 
for their money, can seldom afford to pay the western breeder a fair price for his horses. This credit system has resulted in each local dealer having his certain line of customers, who will buy of him and no one else. Even in good seasons, when money is plenty, the ranchman would have difficulty in competing with him or his own ground.

Lastly, the southern market is best only from November until April, a season at which range horses cannot be had in first-class sale condition, without expensive feeding.

We are aware some fairly satisfactory sales of western horses have been made in the south, but we do not think the average western shipper would be pleased with the result, should he hold his matured stock, and place them on that market.

Our own experience in the past, will not justify our operating in that field to any extent in the future.

\section{Shipping Season.}

The exact time of year when the eastern markets are most available and profitable for the range breeder, is a matter which is of sufficient importance to warrant more consideration than is usually given it. While generally speaking, he can ship any time after the stock gets in first-class condition in the spring, until they begin to look rough and shaggy in the fall and winter, there are portions of the season when the market is much better than at others.

While there is a somewhat stronger demand for business horses during the very early spring, it is difficult to see how range raised stock can be gotten in proper sale condition at that season, at least without liberal feeding throughout the entire previous winter. We doubt whether the expense involved by this plan. will be offset by correspondingly greater prices received for the stock.

At no time during the year does a range horse look better, than when first thoroughly fat in the spring. As the season advances, his coat becomes more or less sunburned, and while he may be in firm- 
er flesh and thus ship a trifle better, there is another circumstance in favor of early shipments which will counterbalance this.

Our experience has uniformly been, that prices are highest at the opening of the season and decline steadily until the close. The reason of this being, that the horses are bought for actual service and as the season grows shorter, the demand is correspondingly weaker. This tendency toward lower prices, will be particularly marked during the late summer and fall of this zoming season.

By no means make the mistake of sending forward thin horses in the haste to strike an early market. Always hold them until fat, even if necessary to delay shipment until September, in order to have them in good condition.

Those breeders who intend to market a considerable number of horses, can usually profit by sorting their stock, and making several different shipments. We would advise these extensive shippers, to forward their dry stock (geldings and barren mares) at the earliest date that they are in proper condition. The yearlings and two year olds, (if these aged colts be shipped, which we consider doubtful policy,) can usually be placed to better advantage in the latter part of summer. But the greatest benefit to be had from this plan of sorting shipments, is in the brood mares with foals by their side. For some unknown reason, eastern people will pay more for sucking colts than any other aged stock, in proportion to their real value. During the season just past, when prices for - all classes of common horses, especially western stock, ruled lower than ever before, we sold hundreds of sucking colts at prices ranging from $\$$ I 5 to as high as $\$ 40$ per head. An average of about $\$ 20$, for ordinary, fairly developed colts, is not far from the usual figure, during September and October. On any considerable number of mares with colts, the additional amount realized from the sales of the sucklings should prove an item well worth saving. But to secure the prices quoted, the colts must be old enough to wean safely-say three months at least, which will of course necessitate holding the mares on the range until later in the season.

There are two peculiarities in the general movement of western horses to the east, that should be noted and utilized by the ranchman, seeking the best market.

Invariably during the latter part of July and first weeks in August, there is less stock on the market than at almost any other period of the season. This is an excellent time to place western stock at good figures, as the supply is seldom equal to the demand.

The other singular fact is, that just at the close of the season, when the horses as a rule are rough coated and in generally poor sale condition, the run of stock is especially large. The approaching winter, with its period of comparative idleness for most users 
of horses, makes it very difficult to effect sales even at low prices. At the close of last season, we were compelled to decline a large number of shipments, because of its being impossible to dispose of the stock, at prices satisfactory to the owners.

If these late shippers would arrange to reach the eastern markets during the dull part of summer above noted, they would be the gainers by many dollars.

\section{Have Shipping Stock Fat.}

Nothing is of greater importance in selling western horses in the east, than their condition. The long, rough trip from the ranch cuts them down severely at best, so to insure their arriving in even fair sale shape, they must be thoroughly fat when started. Not "good order" or "fair condition" but fat. Just as fat as they can get.

There is no one point, the value of which we have labored harder to impress upon the western horseman, who contemplates shipping his stock, than this. IVe can sell old horses, small horses, "renegades," horses with the entire alphabet burned all over them, but we cannot sell thin horses. A thin horse always has a rough, woe-begone look, that makes buyers distrustful at once. No matter how well bred or of how much real worth a colt may be, if he is thin, he will not bring as much as the scrubbiest "cayuse" on the range, should the latter, (as he usually is) be rolling fat.

Western horses must sell on their appearance alto- 
gether and no thin horse shows to advantage, while a plump animal has naturally more or less beauty to recommend him. If you have range horses to sell, never forget that fat covers a multitude of sins. Remember also, that you cannot fatten them up on the road or after you reach market. They must leave home in that condition. Even if you have to hold them until late in the season, never ship them unless they are fat ! FAT! FAT!

\section{What Not to Ship.}

From our frequent assertions in previous pages, that the east is the only available market for western horses, the reader may infer that there is no choice left in making up the consignment; that the ranchman must ship everything which he wishes to dispose of. While it is unquestionably true, that to sell any number of horses they must be placed in the east, yet every western breeder has some animals in his herd which he had better sell at home, even at a sacrifice, rather than chance the expense of marketing them in the east.

First of these are the crippled horses. The curbed, ringboned, broken-hipped and otherwise badly injured stock cannot be giv'n away in the east. If impossible to sell them at home, get what work you can out of them, or let them die on the range. Even splints, glass eyes, bad scars from barb wire cuts and all such blemishes, are poorly received by eastern buyers. To these add off-colors, such as dirty grays, buckskins and muddy roans. Horses of this kind will do as much work as perfect animals, but they will 
not sell for good prices to the eastern trade. Use them up in hard work on the ranch, or sell them to a neighbor for the same purpose.

Next, do not ship colts,--yearlings and two year olds. We are often asked to place this class of stock, but prefer not to handle it when possible to avoid doing so. Matured western horses are bought by consumers for what thcy are, for the work they can see in them, but young stock must be grown, and farmers do not like to buy western colts of unknown breeding and take the chances of their turning out good salable animals. They can be sold in the east, but at prices almost invariably unsatisfactory to the owner. Our advice to ranchmen, if they do not wish to hold their colts on the range until three years old, (which seems to us the best policy), is either to sell them at home, or trade them for matured horses which can be shipped in their place.

Do not ship stallions. They are almost certain to damage the other stock in the cars, and they will bring very low prices in proportion to their real value, if offered on the open market. No eastern buyer wishes to take the risk of altering them. If the breeder is closing out his herd and has stallions to dispose of, he had better sell them to a neighbor or exchange them for marketable geldings. If this is impossible, convert them into work horses.

Next comes the ponies. Nearly every breeder has a few of these scrubbiest of scrubs in his band. Little, scrawny, slab-sided "cayuses" that are in some way accumulated on every horse ranch, either from the Indians or as catch colts. While some small horses will, if fat, sell exceedingly well in the east, often bringing more in proportion to their actual value than really better stock, these miserable little beasts to whom we are now referring, should never be included in a shipment of even fair horses. They hurt the standing of the better animals, and moreover, they will not repay the freight. Dispose of them in some way at home; kill them if there is no other possible method of getting rid of such an encumbrance, but do not ship them.

The western horse that sells best on the eastern markets, is a smooth, sound animal, thoroughly fat, from three to six years old, not less than fifteen hands in height and weighing 1000 pounds and upward. The more size and beauty, the better the price.

While all shipments cannot come up to this standard, and horses that are inferior in size, age and breedins, can be sold for all, and often more than they are worth, yet the shipper can profitably exercise care in the selection of his consignment. For such animals as we have mentioned as being unsalable, will not only not repay the cost of marketing them, but they will injure the appearance and reputation of the whole shipment. No matter if the stock is of generally poor quality, have them all sound, and of as good colors as possible. 


\section{Points on Shipping.}

One of the most important items in marketing range horses, is the condition in which they arrive. It makes no difference how good the stock is when shipped, if it is placed on the market thin and knocked to pieces by the trip. It is a hard jaunt at best and the shipper should use every possible care to make it as easy as he can. Of course, many mistakes are made through inexperience, but we think the hints given below, will prove of some assistance to those ranchmen who have never before shipped horses to the east. IVhile only repeating matter that we have published many times before in various forms, and which is doubtless familiar to many of our readers, yet this pamphlet may reach some breeders to whom the suggestions may be of value. For this reason we reproduce them.

\section{Cars.}

If you use the common stock cars furnished by the railroad company, satisfy yourself that they are sound and perfect, both as to floor, slats, and door fastenings. If not, do not accept them. The company will furnish good ones if insisted upon, and they will not pay for any damages arising from defective cars. See carefully that there are no nails, splinters, or other dangerous projections on the inside of the car. One little nail will often cause many dollars loss.

There are several sizes of the ordinary stock car, but we consider the 34 foot the best and most economical, as they are a trifle wider and much higher inside,

If the slats are too wide apart, insist on its being remedied by nailing a narrow strip between them inside. There is much danger of a horse kicking his foot through where this is not done, and with his leg once fastened there, the chances that he will not be ruined are decidedly small.

Be sure the cars are bedded well with sand, so the horses will not have a slippery footing.

We are often asked, whether the western shipper can profitably use the Palace or Stable Stock cars. While there are several points for and against the three or four most popular lines of these cars, experience has convinced us that the ranchman can employ them with benefit. The feeding and watering facilities will enable him to make longer runs and consequently better time, and the larger dimensions in every way, will lessen the danger of bruising the stock. 
West of Chicago, we believe the car companies make no rental charge for their cars when loaded with range horses, and the slight additional freight tariff is fully compensated by the increased carrying capacity. Being 36 feet long, enough more horses can be shipped to make it up.

There seems to have been some difficulty experienced by the western shippers last season in procuring these cars promptly. They should be ordered of the railroad agent at the shipping point several weeks in advance, and shippers should be particular to state that they want them for horses. If your stock is to be consigned to us and you desire stable cars, order them of your railroad agent, and at the same time write us, giving the expected date of shipment, number of cars needed and the particular make of car desired. If we have two or three weeks notice, we can take the matter up with the car company and usually get them there on time.

This matter of ordering cars of your freight agent in ample time before needed, is important even if using the common stock cars of the road. Always write for them at least three weeks before the time you intend to ship. Annoying delays waiting for cars are thus done away with.

\section{Loading.}

One of the most frequent causes of bad results in shipping horses, is improper loading, more particu- larly overcrowding. Horses should be loaded exactly right to bring them through in the best shape. Loose enough that if one lies down he can get up readily, and still so snug that they will not bruise themselves jostling around.

The idea seems tu be with many shippers, that a car should hold all the horses that can be crowded into it. It is poor economy trying to save $\$ 10$ in freight, at a cost of $\$ 100$ in horse flesh. The horses will fret and fight, because of the intense discomfort. and if one gets down it is very liable never to get up again; while if properly loaded, horses are seldom, if ever, troublesome about getting down.

Never go to the opposite extreme and load too light. With the car only partly filled, the stock is much more liable to be knocked around when the car is handled roughly, and further, the freight charges being so much per car, the cost per head is largely increased when it is not fully loaded.

The rule is about 23 animals to a 34 foot common stock car, and one or two more if you use a stable car. Smaller cars in proportion. It varies, of course, depending on the size of the horses, this being on a basis of good stock, averaging about 1000 pounds.

In loading, see that the bridges are firmly in place and that the stock is not crowded and jammed in the chutes. This is particularly needful in the large stock 
yards, as the employees are often very rough and careless in handling horses.

\section{Shipping Sucking Colts.}

There seems to be a great difference of opinion among breeders, as to the best way of doing this. We have personally tried several plans and always had the best success, loading them in the same car with their dams. Allow the space necessary for a full grown horse to $2 \frac{1}{2}$ or 3 colts, according to size. For example-A car that would hold 23 or 24 srown horses, should be loaded with 16 or 17 mares with colts, according to size. The little fellows will often stand the rough usage of shipping, better than the matured stock.

The plan of shipping them separately in a car by themselves, has not proved very successful, because it deprives the colts of necessary nourishment for so long, and further, the rough work of separating them from their dams at each feeding point, worries and consequently cuts down the stock in flesh, even if none are seriously injured, which usually happens.

\section{Feeding in Transit.}

Do not try and save money by economizing in feed in transit. You will only loose in the end. Feed them every pound they will eat up clean. Always see to it personally, that your stock is fed and watered immediately after unloading; that the quality of the hay is good and that you get the amount you ordered. If there is any negligence in this respect, or any attempt to defraud you in weight, a vigorous protest where it will do the most good, will generally straighten things out.

No matter how short the run, always put feed in the car before loading. If you use stable cars, there are, of course, feed racks provided; but if you are shipping in ordinary stock cars, you will find from 200 to 400 pounds of good hay scattered on the floor before loading, the very best investment you can make. Never neglect an opportunity that will tend to help bring your horses through in better order. It means more money in the end. Keep them eating from start to finish.

\section{Railroad Pastures.}

Partly through our efforts, several of the leading railroads running into Chicago, have established pastures for stock in transit, located within easy reach of the city. The Chicago, Rock Island \& Pacific, and the Chicago \& Northwestern Railways in particular, have gone to considerable expense in arranging these lay-over pastures, and have provided excellent accomodations for shippers wishing to rest up their horses after the long trip from the range.

After seeing the practical benefits of this plan, during the past two seasons, we strongly advise all ship- 
pers to take advantage of it. They will be the gainer in several ways by so doing.

The journey from the extreme west is necessarily severe on the stock, and on reaching. Chicago, they are invariably tired out and badly gaunted. In this condition they cannot be placed on the markets, at least with the expectation of realizing anything near full value for them. But a very few days of quiet and rest, combined with good grazing, will make many dollars difference in their sale. They will fill up, act brighter, and many of the marks and scars of shipping, will have time to heal and disappear.

Another point - if forwarded on to the east, as most stock must be, the cars can be re-loaded at the pasture and transferred to the eastern lines outside the city, without coming to the Union Stock Yards at all. This saves the shipper the 25 cents per head yardage charge exacted by the Stock Yards company, besides the heavy feed bills necessary if unloaded there. He can keep his stock for several days on pasture, at the same or even less cost than holding them over one day at the Stock Yards, and they will improve infinitely more on the grass. Further, the shipper who has not consigned his stock, and who is uncertain as to where to place them, can leave them on pasture and come himself to the city, to invest:gate the probable market. We invite all such to call at our office (77 Exchange Building, Union Stock Yards) before deciding what disposition they will make of their horses.

\section{Trains and Running Time.}

As a general rule, do not keep stock on the cars more than twenty-four hours. Of course, there are exceptions where by running thirty hours one can make time profitably, but eyery hour they are in the cars after that, injures their market value materially. And always allow from twelve to twenty-four hours for feed and rest. Even when shipping in stable cars, where you have facilities for feeding and watering in transit, it is not a good idea to run much more than thirty to thirty-six hours without unloading, to allow the stock to rest and move about. Moreover, by all means give them a few days in the railroad pasture mentioned above.

Horses are very different animals from cattle to ship properly, as they require much more care to bring them through in condition for market. There are so many things that tend to help or injure their sale, while with cattle, it is merely a question of weight and shrinkage.

There is nothing gained in rushing them through. There is much more profit in taking it moderately, allowing them plenty of time for rest and feed ar.d making time when on the road.

Always be sure of going out on a fast through train and never allow the yardmaster to put you on a local 
freight. If necessary; lay over a few hours longer to get on a fast freight; the stock will do much better in the feed yards, than bumping along on a slow train, and will get there quicker in the end. If you are being run slow and side-tracked often and your stock has been on the cars over time, do not blame the trainmen; they are as anxious to get through as you can possibly be. Do your "kicking" where it will have some effect. A personal telegram to the local superintendent or train dispatcher, will generally expedite matters very materially.

In conclusion-as the price realized for the horses depends largely on how they have stood shipping, the breeder cannot be too careful of them while on the road. Every attention on his part means money in his pocket in the end.

\section{Prospects for the Coming Scason.}

We stated many times last season through circulars, etc., that, in our opinion, western horses would sell for higher prices last year, than they ever would again. We referred, of course, to unbroken, branded stock of medium to poor quality, as these grades compose nearly ninety per cent of the western horses shipped to the east.

IVe can see nothing in the present trade or the future outlook, which does not tend to make us still more certain of the correctness of this judgement.

The ordinary and poor grades of westcrn stock, will not bring quitc as good prices this coming scason as they did last, but they will sell a great deal highcr than in 1893 .

The values of native raised, broken horses are declining and the western stock must depreciate even faster. The ranchman who does not recognize this tendency, and act accordingly, will surely regret it.

The advantage of comparatively early shipments will be greatly enhanced this coming season, because of the presidential campaign during the fall, The 
interest and general excitement which this event always arouses, and its effect on every branch of trade, cannot be fully appreciated by the ranchman, living as he does, remote from the great centers of population. Public interest is so centered in this one great question, that it is difficult to attract buyers for anything, and still more so for western horses. If this effect is as marked during the coming election as it was in 1888, we will be unable to handle any volume of trade for the two or three weeks previous and immediately following election. Therefore, we would advise shippers to send their stock forward rather early, in preference to holding it until the latter part of October and first of November.

We have our own arrangements for the coming season well in hand, the most of our markets selected, and our preliminary advertising will soon be preparing the field. Our frequent reminders reach every possible buyer in the chosen territory, and will have the-effect of inducing him to defer his purchase until he has inspected our stock. Every argument that our skillful and experienced advertising manager can contrive, will be advanced, to convince every horse buyer of the endurance and other good qualities of range bred stock.

IVe cannot, of course, as yet quote definite prices, but we will be pleased to do so as soon as the season opens. All inquiries on this, or any other subject pertaining to the western horse trade, we will answer promptly at any time.

\section{"What Will They Bring?"}

This is a question more frequently asked us than almost any other, and it is the most difficult to answer definitely and satisfactorily.

The selling value of all classes of horses depends to a very great extent on their beauty and quality, as well as size, age and breeding. This is more true of unbroken, western horses than any other grade, because they have no developed qualities to give them additional worth. They must sell on their looks.

For example:-A breeder writes us he has so many horses of a certain age and size, which he thinks of shipping to us, and he wishes to know exactly what they will bring. When we come to sell them, an animal weighing only 900 pounds may be easily placed for $\$ 125$, while another in the same car load, weighing I 300 pounds, is hard to dispose of at $\$ 60$. The smaller horse has style, action and beauty, and the other is rough, coarse and ungainly.

From this instance, which is not imaginary, we trust our readers can appreciate the difficulty of quoting definite prices on horses we have never seen, 
and understand why we are obliged to give such a wide range to our figures, in estimating the probable selling value of a consignment. No written description can be sufficiently accurate, to enable anyone to quote the exact worth of the stock.

Unbroken, western horses are really wort/ what they can be made to bring, and breeders selling stock through us, are assured of realizing every dollar that can be gotten for their horses, on the very best markets the country affords.

\section{Ourselves.}

Although it is only about two years, since we established our present business of handling range bred horses on commission, we feel confident that many of our readers are acquainted with us by reputation, and a comparatively large number personally.

We believed at the time we inaugurated our new enterprise, that there was a real necessity for some organized system of selling these horses. Concentration is the great movement in the business world today, and in nothing did this seem more desirable, than in marketing western horses. As in every line of business, the greater the volume handled, the less becomes the percentage of expense. So we reasoned, that if the scores of more or less well directed efforts of individual ranchmen to dispose of their own horses, could be all turned into one channel, better results and less proportionate expense could be accomplished. This we have endeavored to do, and our success so far has greatly exceeded our most sanguine anticipations.

As every breeder who has ever attempted to place his own horses in the east is fully aware, the business is attended with many difficulties. This has been more particularly the case during the past two years. 
With good, native raised horses cheap and growing cheaper, it is not an easy matter to induce people to invest in wild, western stock, against which there is such a general prejudice.

While the first seascn of our new venture greatly exceeded our expectations in the amount of stock handled, yet it did not prove remarkably profitable, and in many respects the system did not work so smoothly as we could have wished. But profiting from past experience, we were much better prepared for the enormous business which we placed last year. From the data kindly furnished us by the various railroad companies, we find thai we handled during the season of $189 \mathrm{r}$, nearly onc-lualf of the entire number of horses, shipped to the east from the western ranges. This unquestionably makes us the largest dealers in unbroken, branded horses in this country, or in the world.

While this rapid growth in the extent of our business is naturally very gratifying, we have a much greater cause for satisfaction, in the knowledge that almost uniformly our many patrons have been pleased with the manner in which their interests have been hanled. There are of course some exceptions, and of these we have a word to say in another place.

However, the fact that a large proportion of our present trade comes from breeders for whom we have previously sold stock, should be sufficient comment on our methods of doing business.
The most critical cannot but admit that our enterprise has passed beyond the experimental stage, and is now a firmly established feature of the western horse trade. We have been constantly making such additions to our facilities, as experience has shown to be of benefit. While, in common with everything else in this world, our system is probably not absolutely perfect, yet we feel that we can honestly claim to offer the western breeder, the very best method of turning his horses into money, that he can find today.

We can give him every advantage that can be derived from large experience and its consequent knowledge of this trade, and the many valuable aids that can only be had, by handling a very large volume of business.

To sell western horses promptly and for the very best prices, in these days of low values and strong competition, requires not only the selection of the best known markets, but when found, these markets must be thoroughly developed. Expensive advertising, the best locations, and skillful, experienced salesmen, are absolutely essential. Even if the individual ranchman could secure all of these, the cost would be so great as to eat up the entire proceeds of his shipment. On the other hand, we do not handle one car load, or ten, but hundreds of car loads and thousands of horses every season. While the aggregate expense is enormous, divided up among so 
many, the amount per head is comparatively small.

We can give the-ranchman the benefit of the best of everything, and at a less cost than he would incur in marketing his stock unaided. At the opening of the coming season, June Ist next, we will be more fully prepared than ever before, to receive consignments of any number of western horses and can guarantee our patrons the best returns from their shipments, that it is possible to secure. We can get the highest prices obtainable and can sell the stock promptly.

To those ranchmen who are going to ship unbroken range horses with the idea of realizing an average of $\$ 100$, or $\$ 75$ per head net for them, we wish to say frankly, do not consign them to us. We can not get that price for them and we do not believe there is any one in the country who can. But from breeders having good, smooth stock, which they wish to convert into money, getting for them every dollar possible and that with no delay, we earnestly solicit consignments, and are confident that a trial shipment will lead to further and more extensive business relations.

We wish also to take this occasion, to thank those who have favored us with their shipments, during the past two seasons. Their encouragement and good wishes, not less than their practical business support, have contributed very greatly to the success of our undertaking.

\section{The Dissatisfied.}

In stating in a previous chapter, that we had almost uniformly succeeded in pleasing those western breeders for whom we had sold stock, we also mentioned that there were exceptions-men who, at the time, and even now firmly believe we dealt unfairly with them. Nothing is more natural than for these men to express this opinion to their neighbors, or to any horseman with whom they come in contact, and we do not blame them in the least for so doing, providing they are honest in their belief.

Stories of this character, as a matter of course, work more or less injury to our business in certain localities and it is only because of this, and our manifest inability to reply to each complaint separately, that we refer to the matter here.

We know positively, that each and every instance of dissatisfaction, has arisen from one and the same cause only. Lack of knowlidgc of what stock of this class is really worth.

To illustrate:-we receive a consignment from a breeder, who has not shipped any of his horses to 
eastern markets for the past three or four years. Perhaps he sold his surplus stock, two or three years ago, to an eastern speculator, and has been holding them since then hoping to effect a similar sale. In the mean time, he has been retailing an occasional horse at home for good figures, say, $\$ 65$ to $\$ 100$ per head.

However, the accumulation of his matured geldings, combined with the necessity for ready money, has decided him to ship them.

Not wishing to attempt to dispose of them himself, he consigns them to us. We place them on what we know to be one of the very best available markets in the country, for such stock as this breeder has to sell, advertise them extensively, send our best salesman to handle them, in fact use every resource at our command to get the utmost dollar possible for the stock. As the result, we effect a really good sale of the horses. Possibly, as has often happened, we have expended more money in the effort to made an exceptionally good sale, than we receive in commissions.

But the owner has fixed his ideas of value, by the standard of prices received several years since and by the amount realized for the horses retailed at home; and he has the firmly grounded opinion, that this entire shipment is worth that much. He expects to receive that average per head, or he would not have shipped them.

When we render him an account sales, showing that his consignment has brought him nct, over and above all expenses of freight and commission, say $\$ 50$ per head, there is an explosion. He has been confidently expecting from $\$ 20$ to $\$ 40$ per head more than that, so what is more natural than for him to blame us for the result. We are the salesmen, and consequently, in his opinion, responsible for not getting more money for the horses. With his limited experience, nothing will convince him that the market and not ourselves, is to blame; and he returns home, firm in the belief that we have in some way defrauded or swindler him. When, as is often the case, the horses are extremely well sold at an average of $\$ 30$ per head net, and the owner has been valuing them at $\$ 75$, the degree of censure is just that much increased.

Curiously enough, many of our largest patrons and firmest friends, are breeders who were extremely dissatisfied with the first consignment which we placed for them. However, one or two subsequent trials of the market on their own account, showed them conclusively that we could be of aid to them in disposing of their horses, and we have since then had their entire business.

IVe cannot help the condition of the markets, nor can we make the stock bring higher prices than buyers will give. IVe can sell the horses quicker and for more money, than can their owner unaided, but to get for them just what the owner happens to value them at, simply because we make the sale of this 
stock a special business, is very seldom possible in these days of low prices and hard sales.

Small, unbroken, branded horses are depreciating so rapidly, that it will not be long before the very ranchmen who protested so forcibly at last season's low values, will consider themselves fortunate at having sold a portion of their stock at those prices.

We crave our reader's pardon for dwelling at such length on this unpleasant matter, but in justice to ourselves, we could not neglect this opportunity of explaining the true cause of these scattering complaints. We merely wish to add, that no breeder who has ever consigned stock to us, can truthfully claim that he has received any but fair and business-like treatment.

\section{Are These P'oints of Value to You?}

The ranchman can easily satisfy himself of the ad. visability of consigning his horses to our firm, by considering carefully the following points. While they are items that go to make up our comprehensive guarantee of prompt cash sales of this stock, for the best obtainable figures, we believe a detailed consideration of them, will enable the reader to more readily form his estimate of the value of our proposition to himself.

\section{A Definite Market.}

The breeder consigning his horses to us, is saved all worry as to where to ship his stock. He avoids all the indecision and apprehension regarding his market, and further, he can take advantage of through rates on his shipment. He need not, (as many ranchmen do), bill his stock to one point, hoping to effect a sale; failing to do so, shipping them to another and so on, paying local rates each time, which runs up the amount of his freight charges to an cxcessive figure. By consigning them direct to us, he is certain of placing his stock on the very 


\section{Best Markets.}

Having investigated the field thoroughly, and made a careful study of this most important matter, we know' to a cirtainty those points, where this grade of horses will bring the highest prices--where the demand is strongest and the prejudice against them the least pronounced.

\section{Advanced Freight Charges.}

Often the breeder has not the ready money at hand, to pay those charges for freight and feed in transit which the railroads insist must be settled before the stock will be released, and it may not be convenient, or it is unpleasant to borrow it. We pay the freight charges on all stock consigned to us, deducting them from the proceeds of the horses, when sold. If his stock is billed to us, the shipper need take with him only the amount necessary to pay his personal expenses on the road.

We are also glad to accomodate our patrons, should they be in need of funds before stock is closed out and settled for,

\section{Experienced Salesmen.}

The price received for anything, depends almost invariably on the ability and experience of the salesman. Nothing is of greater importance.

Our salesmen for this coming season, have been selected from the large number we have tried during the past few years, and we know that no better can be secured. WV certainly would not pay them salaries ranging from $\$ 50$ to $\$$ I 50 per week, did we not consider their services worth that amount.

It stands to reason, that a man who makes the sale of these horses a specialty, who does nothing else but handle them every day throughout the season, and has been doing this for years, can secure better prices than the breeder who has little or no experience, and who cannot know what his stock is really worth on the market.

\section{Fixed Expenses.}

The ranchman consigning stock to us, knows in advance just what it will cost him to market his horses. There are no feed bills, and the hundred other expenses, which count up so rapidly when placing them on his own account. The one item of our commission, covers every expense except the freight charges.

\section{Quick Sales}

are of the greatest importance to the western breeder in more than one way. Almost without exception, he has home interests that require his personal attention, and which suffer during his absence. His time is valuable, and he cannot afford to spend two or three months (as many have done and must do, when placing their stock unaided), peddling out a few horses. 
Ordinarily, we can close out a consignment of any size, within a very short time, usually not more than two or three days after they arrive at the place of sale. We have often received a shipment in the morning and sold every animal before night. It is preferable, however, to give the horses a day or so to rest and fill up, which gets them in the best sale condition.

Neither do we slaughter the stock regardless of value. Our patrons are always consulted regarding sales, and should the market not be satisfactory, we move the shipment to some other point at our own expense.

Another benefit of prompt sales, is that the horses are disposed of before they begin to fall away. All breeders who have marketed their own stock, will ap preciate this point. Western stock that has shipped in good shape, will look exceedingly well when first filled out after arrival; but in the course of a very few weeks they will begin to grow thin, and no amount of feccling will keep them in condition for sale. This is probably caused by the hard trip and change of feed, but whatever the reason may be, the result is disastrous to the owner, and can only be aroided by selling them as soon as possible after they are fit to offer.

\section{Retail Sales.}

We sell all horses at retail, direct to the consuner. and in this way secuse for our patrons every dollar their horses are worth. IVe sell them on the same markets as would a speculator, if the breeder should sell his stock to one. As the dealer's expenses would equal our commission, our patrons can realize the same net amount for their stock, as would the speculator.

Why sell your horses to a trader, (if you can do so, which is very doubtful) and allow him a profit on them, when you can get the same price for them that he can, and without the slightest effort or trouble to yourself in so doing?

\section{Cash Sales.}

While the ranchman can occasionally sell a shipment in the western farming states, or on the road, almost uniformly he must give credit for part or all of the amount. Notes, (especially if of dubious quality) are not nearly as useful as money, in settling accounts at home. We place our patrons stock in localities where it can be sold on a strictly cash basis, and all consiguments are sctuled for in spot cash-drafts on currency ats dewirul.

We insure al thes lenefits to our patrons.

Are they not worth onsidering, before you decide whether you ta:ie the chances of selling your stock rourself, or letting us do it for you? 


\section{Terms.}

Our rates of commission for selling range horses are as follows:-

Fiffecn per cont on the gross amount rialined for the stock.

All horses selling for less than $\$ 50$, to pay a full commission on that amount. In other worts, the minimun charge is $\$ 7.50$ per head. This rule does not apply to sucking colts sold with their dems. Eiacn if sold scparately, the mare and colt will be connted as onc animal.

This commission includes the parment of all ixpenses by us,aftcr the stock is delizered at such points as a'c may dircet.

The freight charges, including of course feed in transit, and our commission at the rates above given, are the only items deducted from the gross sales of the stock. IVe make no charge for feed, or any extra whatever. As we sell the horses consigned to us, at points east of Chicago, the freight charged against the stock, is to the final destination or place of sale. We take charge of it at that point and paty all further expenses.

While some broclers, who have had little experience on eastern markets, may, at first glance, consider our charges a tritle high, we think further consideration and a trial of our system, will convince them that the rates are really reasonable. We could, with equal profit to ourselves, lessen the rates by reducing the expenses of sale. But we have learned from many trials to this end, that quick and cortain salcs can only be insured, by using every advantage given by competent salesmen, liberal advertising, expensive locations for sale etc. The necessaay outlay for these, is returned many times over in the promptness of sales and the higher prices received for the horses. It is good business policy, to expend a dollar when there is a certainty of getting several in return for it.

A trial consignment will easily demonstrate the true economy of our proposition, and we earnestly request this trial. 


\section{Special Instructions.}

We will esteem it a great favor, if shippers consigning stock to us will carefully observe the few points given below. It will greatly assist us in handling their interests to the best advantage.

Determine as nearly as possible, the probable date of shipment, then advise us by mail, giving good general description of the stock and exact date you expect to forward it. This will enable us to allow for it and to have all arrangements made for placing it promptly. Also give probable route viz: the different lines of railroad over which you expect to come.

It is not necessary for the owner to come with his stock, and should he not wish to do so, the shipment should be in charge of a reliable man, who will attend to it carefully. If desired, we will take charge of consignments at Chicago and forward them to market in care of our own men.

The owner when not coming with his horses, should alway's advise us by letter as to how he wishes settlement made; whether with man in charge, or by remittance direct to him.

While we give every consignment the same care and attention, selling the horses as quickly and for the highest possible prices, whether accompanied by the owner or not, yet we always piefer that the owner or his accredited representative be in charge of the shipment.

When the horses are loaded, telegraph our Chicago office, giving name, number of head etc., so we can locate the consignment en route, if necessary.

Bill your horses direct to $T$. H. Spanlding \& Co., Union Stock Iards, Chicago, and unless otherwise instructed by wire, stop the stock off at the railroad pastures, in place of allowing them to be brought direct to the Stock Yards. We have fully explained the advisability of this, on page 40. If you should not care to come on to the city, our agent at the pasture will arrange to forward the stock etc.

Should there be a railroad accident, causing loss or injury to your horses, wire us immediately. The shipper in charge, should proceed with such horses as are uninjured, leaving the damaged ones with the agents of the railroad company. IVe will attend to all claims of our patrons for damages against railroad companies, without charge.

Should any further instructions be desired, we will furnish them promptly by nail.

Address plainly-

T. H. Spaulding \& Co., 77 Exchange Building, Union Stock Yards,

Chicago, Ill. 


- 


